Original Article

\title{
A STUDY ON CEPHALIC INDEX OF ADULT NORTH INDIAN POPULATION
}

\author{
Prem Singh, Vasundhara Kulshreshtha, Pradeep Singh, Ved Prakash \\ Department of Anatomy, S.N. Medical College, Agra, UP, India
}

\begin{abstract}
Introduction: Cephalic index is the percentage of head breadth to head length. The index is calculated from measurement of the diameters of head (head length and head breadth). When applied to living individuals it is known as cephalic index, and when referring to dry skulls, the cranial index. This index is used as a useful anthropological tool for analysis of racial and sexual differences in a population. The present study was done to find out Cephalic Index and to study sexual dimorphism in adult North Indian population. Objective of the study was to calculate the cephalic index and to find out that the present study group belongs to which category in the classification of skull based on cephalic index and to study the sexual dimorphism in respect to cephalic index.
\end{abstract}

Material \& Methods: The present study comprised of 200 medical students of age group between 18 yrs. to 25 yrs. of S.N. Medical College, Agra, not having any significant disease or deformity that could have affected the general or the bony growth.

Two anthropometric parameters; head length and head breadth were recorded in centimeters by using spreading caliper. With these recorded data, cephalic index was calculated for males and females separately as well as combined.

Results: Mean Cephalic Index was significantly higher $(p=0.03124)$ in females $(79.350 \pm 5.7157)$ as compared to males $(77.715 \pm 4.9102)$.

Conclusion: There was a statistically significant difference in the mean of the cephalic indices of male and female students $(p=0.03124)$. The mean cephalic index of combined population in this study was $78.533 \pm 5.3776$ which states that the dominant head shape among North Indians is Mesaticephalic.

Keywords: Head length, head breadth, anthropology, spreading caliper.

\section{INTRODUCTION}

Cephalic index $(\mathrm{Cl})$ also called as cranial index or Index of breadth is one of the important parameter that helps to differentiate between different human races. The cephalic index was defined by Swedish professor of Anatomy Anders Retzius (1796-1860) and first used in physical anthropology to classify ancient human remains found in Europe [1]. The measures used by Retzius, when applied to living individuals are known as cephalic index, and when referring to dry skulls, the cranial index [1].

The cephalic index is calculated by multiplying the head breadth with 100 and dividing it with the head length. It is very useful anthropologically to find out racial and sexual differences [2]. The relevant data on cephalic index of a population is very much essential and useful in designing various orthopaedic and physiotherapic equipments of head and face like cranial remodeling band (helmet), head phones, goggles etc. by formulating standard sizes [3]. Also standardized cephalometric records are useful in anatomy, forensic medicine, pediatrics, plastic surgery, oral surgeries and dentistry etc. [4] and enable diagnostic comparison between patients and the normal population [5]. The dolicocephalic people have otitis media less often than brachycephalics [6]. It is 
also reported that individual with Alpert's syndrome are hyperbrachycephalic [7].

Regarding, the effect of racial, ethnic and geographical factors on head dimensions the present study was done to determine the cephalic index of adult population, to find out the dominant head type and to study sexual dimorphism in North Indian students of age group 18 to 25 years of S. N. Medical College, Agra, Uttar Pradesh, India. The observations and findings of present study will provide a platform for similar cephalometric studies done on various communities, castes, races of particular geographic zones.

\section{MATERIALS AND METHODS}

The present study comprised of 200 medical students of age group 18-25 years of S.N. Medical College, Agra, Uttar Pradesh from North India. Age above 18 yrs has been chosen for the reason that by this age there is almost completion of skeletal growth. The subjects chosen were medical students because of easy availability in medical college. The subjects chosen were apparently healthy and without any visible spinal or cranial deformity. Any subject with congenital or acquired cranial, spinal or bone deformity i.e. scoliosis, kyphosis, etc. were excluded from the study.

Two anthropometric data (head length and head breadth) was taken in centimetres and to an accuracy of $0.10 \mathrm{~cm}$, with the subject sitting in chair, in relaxed condition and the head in anatomical position. Prior informed consent in writing was taken from each subject. Head length was measured as the straight distance between glabella and the opisthocranion, using blunt ended spreading caliper. Head breadth was measured as the maximum biparietal diameter and is the distance between the most lateral points of the parietal bones i.e. between two parietal eminences.

All these measurements were recorded three times to minimize subjective errors, and then their mean was taken as standard. All data were entered on MS excel sheet and the data were analyzed in PRIMER and SPSS version 22 for Windows statistical software package (IBM SPSS Statistics 22). Quantitative data were summarized in form of mean and SD (Standard Deviation). Then the percentage of head breadth to head length was calculated separately for male and female population as well as in combination of both males and females. The difference and relationships were deemed statistically significant when $p<0.05$. Mean $\pm S D$ values of all variables were obtained, and $p<0.05$ was considered to be significant.

\section{OBSERVATIONS AND RESULTS}

Cephalic Index is the percentage of head breadth to head length in any skull. The index is calculated from measurement of the diameters of the skull.

$$
\text { Cephalic index }=\frac{\text { Head breadth } \times 100}{\text { Head length }}
$$

Skulls can be classified into four categories on the basis of cephalic index [8] i.e. Dolichocephalic in which cephalic index is below 75 (in Australians), Mesaticephalic with cephalic index between 75- 79.9 (in Indians, Europeans), Brachicephalic having index between 80- 84.9 (in Chinese, Japanese) and Hyperbrachicephalic with index between 85.0- 89.99 (in Fars males, Iran).

The mean Cephalic Index for males was 77.715 with SD 4.9102, and mean Cephalic Index for females was 79.350 with SD 5.7157. Mean Cephalic Index was significantly higher ( $p$ value 0.03124 ) in females as compared to males. The mean Cephalic Index of combined males and females subjects was 78.533 with SD 5.3776 (Table 1, Fig. 1).

As per Cephalic Index, it was concluded that the present study population belongs to Mesaticephalic (index between 75 - 79.9 found in Indians, Europeans) category.

Table 1: Comparison of mean Head length, mean Head breadth \& mean Cephalic Index between males, females \& combined population

\begin{tabular}{|c|c|c|c|c|c|}
\hline Sex & No. & HL士SD & $\mathrm{HB} \pm \mathrm{SD}$ & $\begin{array}{c}\text { Mean } \\
\text { Cephalic } \\
\text { Index } \pm \text { SD }\end{array}$ & $p$ value \\
\hline Male & 100 & $\begin{array}{c}18.630 \pm \\
0.7356 \\
\end{array}$ & $\begin{array}{c}14.458 \pm \\
0.7511 \\
\end{array}$ & $\begin{array}{c}77.715 \pm \\
4.9102 \\
\end{array}$ & \multirow[t]{3}{*}{$0.03124 \mathrm{~S}$} \\
\hline Female & 100 & $\begin{array}{c}17.361 \pm \\
0.6923\end{array}$ & $\begin{array}{c}13.763 \pm \\
0.7797\end{array}$ & $\begin{array}{c}79.350 \pm \\
5.7157\end{array}$ & \\
\hline Combined & 200 & $\begin{array}{c}17.995 \pm \\
0.9551\end{array}$ & $\begin{array}{c}14.110 \pm \\
0.8393\end{array}$ & $\begin{array}{c}78.533 \pm \\
5.3776\end{array}$ & \\
\hline
\end{tabular}

(HL= Head length, HB= Head breadth, $S D=$ Std deviation, $p=$ probability, $S=$ Significant) 


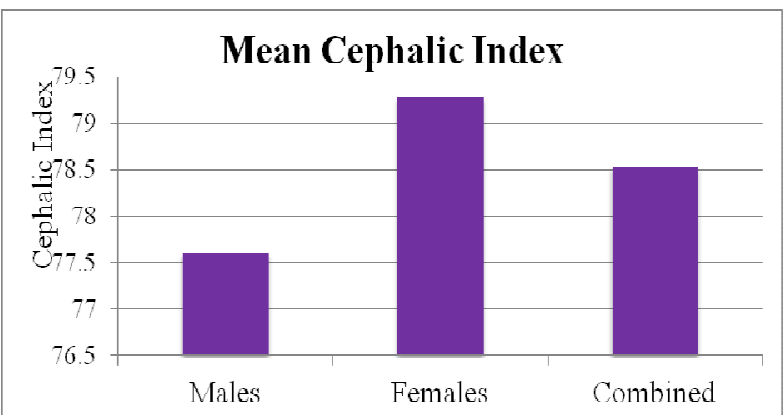

Fig. 1: Comparison of Cephalic Index between males, females and combined population

\section{DISCUSSION}

The present study is based on the measurement of the Cephalic index on the living population. On the basis of cephalic index head shapes were grouped into four categories, i.e. Dolicocephalic (from the ancient Greek Kephale, head and dolikhos, long and thin), Brachicephalic (short and broad), Mesocephalic (intermediate length and width) and Hyperbrachicephalic (very short and broad) [8].

The mean Cephalic index of males was $77.715 \pm$ 4.9102. This finding was slightly higher than Bhils study with 76.98 [9]. But lower than males from Manipal with 77.92 [10], Barelas with 79.80 [11] and Gujarati males with 80.42 [2] of Indian group.

The mean Cephalic index of Indian females in present study was $79.350 \pm 5.7157$. This finding was lower than Nakashima (1986) study in Kyushu with 87 [12], a study on native Fars group with 85 in north of Iran [13], Turkman group 82.8 in North of Iran [4], Shah and Jadhav (2004) from India with 81.20 [2], Manipal females with 80.85 [10]. But higher than study in Tehran- center of Iran with 75 [14], in Croatia with 79.23 [15], ljaw (78.24) and Igbo (76.83) tribes community [16], Baysela state, Nigeria with 72.24 [17].

The mean cephalic index of this study (combined population) was $78.533 \pm 5.3776$ which states that the dominant head shape among North Indians is Mesaticephalic which was lower than Shah and Jadhav study (2004) in India with 80.42 [2], Bhargava and Kher's study (1961) in Berelas of Central India 79.80 [11], study on Manipal population with $78.92 \pm 6.31$ [10], Chile (80.42) by del Sol, Fars males with 84.8 [13], study in Port Harcourt, Nigeria with 79.80 [18]. But the Cephalic index was higher when compared to Abolhasanzadeh and Farahani study (2003) in Tehran-Iran with 75 [14], Bhargav and Kher
(1961) for Bhils of Central India 76.98 [11] and study by Eroje et al. (2010) for Ogbia of Nigeria with 72.96 [17].

This shows that there is tendency towards brachycephalisation. Comparing previous records of cephalic index with recent work proves tendency towards "brachycephalisation" that is an evidence of continuous growth of brain more in the lateral direction [2]. Also, in tropical zones head form is longer (dolichocephalic), but in temperate zones the head form is more round (mesocephalic or brachycephalic) [19]. Since India is partly in temperate and tropical zone, the present classification shows tendency to brachycephalization from dolicocephalic.

\section{CONCLUSION}

The present study has shown the usefulness of cephalic index as a parameter for differentiation of sex in North Indian population and that the dominant head shape among North Indians is Mesaticephalic. Methods used in the study for measuring the parameters are noninvasive, non-time consuming and non-expensive, which do not need any specialized training hence, can be used by anyone.

\section{REFERENCES}

1. Anitha MR, Vijayanath V, Raju GM and Vijayamahantesh SN Cephalic index of north Indian population. Anatomica Karnataka. 2011; 5(1):40-43.

2. Shah GV, Jadhav HR. The study of cephalic index in students of Gujarat. J Anat Soc India. 2004; 53(1):25-26.

3. Singh P, Purkit R. A cephalometric study among subcaste groups Dangi and Ahirwar of Khurai Block. Anthropol. 2006; 8(3): 215-17.

4. Golalipour MJ. The effect of ethnic factor on Cephalic Index in 17-20 years old females of North of Iran. Int J Morphol. 2006a; 24: 319-22.

5. Rabey GP. Craniofacial morphoanalysis. Proc R Soc Med. $1971 ; 64: 103-111$.

6. Stolovitsky JP, Todd NW. Head shape and abnormal appearance of tympanic membrane. Otolaryngol Head, Neck Surg. 1990; 102:322-325.

7. Cohen MM, Kreiborg S. Cranial size and configuration in the Apert's syndrome. J Craniofac Genet Dev Biol. 1994; 14:95102.

8. Williams P, Dyson M, Dussak JE, Bannister LH, Berry MM, Collins P, Ferguson MWJ (eds). Gray's Anatomy. In Skeletal system. $38^{\text {th }}$ ed. London, Churchill Livingstone. 1995, 607-12. 
9. Bhargava I, Kher GA. An anthropometric study of Central India Bhils of Dhar district of Madhya Pradesh. J Anat Soc India. 1960; 9:14-19.

10. Yagain VK, Pai SR, Kalthur SG, Chethan P, Hemalatha I. Study of cephalic index in Indian students. Int J Morphol. 2012; 30(1):125-129.

11. Bhargava I, Kher GA. A comparative anthropometric study of Bhils and Barelas of Central India. J Anat Soc India. 1961; 10:26- 33.

12. Nakashima T. Brachycephalization in the head form of school girls in north Kyushu. Sangyo Ika Dainguku Zussshi. 1986; 5:411-14

13. Golalipour MJ. The variation of head shapes in 17-20 years old native Fars male in Gorgan-North of Iran. Int J Morphol. 2006b; 24:187-90

14. Abolhasanzadeh, A. \& Farahani, M. R. Standarded international classification of head shapes of 22-24 years old in Tehran. J. of Research in Medicine, 26:281-5, 2003.
15. Buretic-Tomljanovic A, Ristic S, Brajenovic-Milic B, Ostojic $\mathrm{S}$, Gombac E, Kapovic M. Secular change in body height and cephalic index of Croatian medical students (Univ. of Rijeka). Am J Phys Anthropol. 2004; 123:91-96.

16. Oladipo GS, Olotu J. Anthropometric comparison of cephalic indices between the ljaw and lgbo tribes. Global J Pure and Applied Sciences. 2006; 12:137-38.

17. Eroje MA, Fawehinmi HB, Jaja BN, Yaakor L. Cephalic index of Ogbia tribe of Bayesla state. Int J Morphol. 2010; 28:38992.

18. Fawehinmi HB, Osunwoke AE, Ligha AE, Okoh PD. A comparative study on the cephalic indices of normal growing children and children with sickle cell anaemia in Port Harcourt. J Exp \& Clin Anat. 2008; 7:27-29.

19. Bharati S, Som S, Bharati R, Vasulu TS. Climate and head form in India. Am J Hum Biol. 2001; 13:626-34. 